\title{
Keanekaragaman Jenis Flora Epifit Di Hutan Kota Pekanbaru, Provinsi Riau dan Kajian Kekerabatannya
}

\section{Diversity of Epiphytic Floras at City Forest Pekanbaru, Riau Province and Their Relationship Study}

\section{Nery Sofiyanti}

Jurusan Biologi Fakultas Matematika dan Ilmu Pengetahuan Alam Universitas Riau Kampus Bina Widya Jl. Pekanbaru Bangkinang KM 12.5, Panam, Pekanbaru, Riau. 28295. Email : nery.sofiyanti@lecturer.unri.ac.id

\begin{abstract}
The city forest of Pekanbaru, Riau Province has many host trees for epiphytic flora. This study aimed to identify the epiphytic flora on tress of forest city Pekanbaru. Samples were collected from the field using exploration method. The morphological characters were scored and analysed to construct dendrogram using NTSyst 2. A total of 35 epiphytic floras were identified in this study, and consisted of mosses (12 species), ferns (21 species) and seed plants (2 species). Dendrogram showed that the examined species clustered based on the similarity of morphological characters
\end{abstract}

Keywords : epiphyte, fern, moss, seed plant.

\section{Pendahuluan}

Flora epifit merupakan golongan tumbuhan yang hidup menempel pada tumbuhan lain. Pada umumnya tumbuhan yang banyak ditumbuhi flora epifit mempunyai permukaan batang yang kasar ataupun berpelepah seperti batang kelapa sawit truktur batang seperti ini membuat iklim mikro yang sesuai bagi habitat tumbuhan epifit.

Hutan Kota Pekanbaru Provinsi Riau, terdiri dari banyak pohon yang ditumbuhi oleh tumbuhan epifit, seperti pohon Rambutan, Mangga, Angsana, Pinang, Cemara, Mahoni dan lain sebagainya. Oleh karena itu kajian ini bertujuan untuk mengidentfikasi jenis-jenis flora epifit yang di jumpai pada pohon pohon di Kota Pekanbaru. Kajian flora epifit di Pekanbaru telah dilakukan oleh Sofiyanti (2013) namun hanya paku epfifit pada Kelapa Sawit saja. Sementara tumbuhan epifit dan tumbuhan inang lainnya belum pernah dilaporkan. Oleh karena itu, kajian ini bertujuan untuk mengidentifikasi jenisjenis flora epifit di Hutan Kota Pekanbaru dan mengetahui keanekaragamnnya.

\section{Metode Penelitian}

Pengambilan sampel

Sampel yang diambil adalah flora epifit dari golongan lumut, paku dan tumbuhan berbiji. dikoleksi dari lapangan mengacu pada Kamau (1992) setiap jenis yang ditemukan didokumentasikasikan.

Karakterisasi, identifikasi dan pembuatan kunci identifikasi

Karakterisasi morfologi dilakukan pada setiap jenis. Identifikasi mengacu pada Piggot (1998) dan Sofiyanti et al. (2015a)., serta penelusuran pada situs : http://natureloveyou.sg, $\quad$ https://rbgweb2.rbge.org.uk/thaiferns/pages/ferns-ofthailand.htm. Kunci identifikasi yang digunakan adalah kunci dikotom

\section{Analisa data}

Hasil identifikasi ditabulasikan dan dibuat skor berdasarkan tabel karakter umum. Hasil skoring dianalisis menggunakan NTSYSTpc 2.2 (Rohfl 2009) untuk mendapatkan matrik similaritas dan dendrogram. 


\section{Hasil dan Pembahasan}

Hasil inventarisasi flora epifit disajikan pada tabel 1 berikut ini.

Tabel 1. Daftar jenis flora epifit yang ditemukan di hutan Kota Pekanbaru, Riau.

\begin{tabular}{|c|c|c|c|}
\hline Klasifikasi & Famili & & Nama Jenis \\
\hline \multicolumn{4}{|l|}{ A. LUMUT } \\
\hline \multirow[t]{11}{*}{ 1. Bryophyta } & Bryaceae & 1 & Bryum coronatum Schwagr. \\
\hline & \multirow[t]{5}{*}{ Calymperaceae } & 2 & $\begin{array}{l}\text { Arthrocormus schimperi (Dozy \& Molk.) Dozy } \\
\text { \& Molk. }\end{array}$ \\
\hline & & 3 & Calymperes pallidum Mitt. \\
\hline & & 4 & Syrrhopodon albo-vaginatus Schwagr \\
\hline & & 5 & Syrrhopodon aristifolius Mitt. \\
\hline & & 6 & Syrhopodon prolifer Schwagr. \\
\hline & \multirow[t]{3}{*}{ Dicranaceae } & 7 & Leucrobryum glaucum \\
\hline & & 8 & Leucobryum aduncum Dozy \& Molk. \\
\hline & & 9 & $\begin{array}{l}\text { Leucobryum candidum (Brid. ex P. Beauv.) } \\
\text { Wilson }\end{array}$ \\
\hline & Thuidiaceae & 10 & Thuidium sp. \\
\hline & Pilotrichaceae & 11 & $\begin{array}{l}\text { Callicostella papillata var. prabaktiana } \\
\text { (Mull.Hal) Streimann. }\end{array}$ \\
\hline 2. Marchantiophyta & Pallaviciniaceae & 12 & Pallavicinia sp. \\
\hline \multicolumn{4}{|l|}{ B. PAKU } \\
\hline \multirow[t]{21}{*}{ Polypodiophyta } & Glecheniaceae & 1 & Dicranopteris liniaris (Burm. f.) Underw. \\
\hline & \multirow[t]{2}{*}{ Apleniaceae } & 2 & Asplenium nidus L. \\
\hline & & 3 & Asplenium serratum L. \\
\hline & Blecnaceae & 4 & Stenochlaena palustris (Burm. f.) Bedd. \\
\hline & \multirow[t]{3}{*}{ Davalliaceae } & 5 & Davallia denticulata (Burm. f.) Mett ex Khun. \\
\hline & & 6 & Davallia sp1. \\
\hline & & 7 & Davallia sp2. \\
\hline & Nephrolepidaceae & 8 & Neprolepis hirsutula (G. Forst) C. Persl. \\
\hline & \multirow[t]{9}{*}{ Polypodiaceae } & 9 & Drynaria sparsisora (Deev.) T. Moore \\
\hline & & 10 & Microsorum puctatum C. Copel \\
\hline & & 11 & Microsorium pustulatum Copel \\
\hline & & 12 & $\begin{array}{l}\text { Phymatosorus scolopendria (Burm. f.) Pic. } \\
\text { Serm. }\end{array}$ \\
\hline & & 13 & Pyrrosia piloselloides (L.) MG. Price \\
\hline & & 14 & Pyrrosia heterophylla (L.) MG. Price \\
\hline & & 15 & Pyrrosia longifolia (Burm. f.) CV. Morton \\
\hline & & 16 & Pyrrosia lanceolata (L.) Farw. \\
\hline & & 17 & Platycerium coronarium (Mull.) Desv. \\
\hline & \multirow[t]{4}{*}{ Pteridaceae } & 18 & Vittaria enciformis SW. \\
\hline & & 19 & Vittaria elongate SW. \\
\hline & & 20 & Vittaria graminifolia Kaulf. \\
\hline & & 21 & $\begin{array}{l}\text { Vittaria scolopendrina (Bory) Schkuhr ex } \\
\text { Thwaites }\end{array}$ \\
\hline TUMBUHAN & BERBIJI & & \\
\hline \multirow[t]{2}{*}{ Spermatophyta } & \multirow[t]{2}{*}{ Orchidaceae } & 1 & Acriopsis liliifolia (J.Koenig) Seidenf. \\
\hline & & 2 & Dendrobium crumenatum Sw. \\
\hline
\end{tabular}

Pada kajian ini ditemukana 35 jenis flora epifit, yang terdiri dari dari tumbuhan lumut (12 jenis), tumbuhan paku (21 jenis) dan tumbuhan berbiji ( 2 jenis) .
Jenis-jenis lumut epifit

Lumut merupakan tumbuhan tingkat rendah yang memproduksi spora dan belum mempunyai berkas pengangkut (Sofiyanti et al. 2017b). Pada umumnya lumut ditemukan di daerah yang lembab dan ternaungi dan 
mempunyai peranan penting secara ekologis (Hazel et al. 2014). Pada penelitian ini ditemukan 11 jenis lumut dari 6 famili, yaitu 1 famili dari Divisi Marchantiophyta dan 5 famili dari Divisi Bryophyta. Setiap jeni syang ditemukan memiliki karakteristik tersendiri, seperti daun merayap rapat, tegak mengembang, tegak rapat, tersusun spiral memanjang, tegak rapat mengembang, merayap serta merayap menyerupai thalus ( Gambar 1). Anggota Divisi Marchantiophyta dikenal dengan Lumut Hati pada umumnya mempunyai karakteristik tubuh bertalus dengan pertumbuhan merayap, bagian ventral ditumbuhi rhizoid dan bagian dorsal mendukung sporofit. Thalus bercabang hampir dikotom dengan bagian ujung berlekuk (Lavate et al. 2018). Jenis Lumut hati yang ditemukan pada penelitian ini adalah Pallavicinia sp. yang mempunyai daun menyerupai thallus (Gambar 1h), yang tergolong Famili Pallaviciniaceae, Ordo Metzaeriales, dan Divisi Marchantiophyta. Jenis-jenis Bryophyta epifit yang diidentifikasi pada kajian ini tergolong dalam family Bryaceae (1 jenis), Calymperaceae (5 jenis), Dicranaceae (3 jenis), Thuidiaceae (1 jenis) dan Pilotricaceae (1 jenis), Jumlah jenis yang ditemukan pada penelitian ini lebih sedikit dari yang dilaporkan Sofiyanti et al 2017. Anggota Bryophyta dikenal dengan lumut berdaun karena sudah mempunyai struktur daun yang lebih jelas dibandingkan dangan anggota Marchantiophyta (Hazel et al. 2014; Crandall-Stotler \& BartholomewBegan 2018).
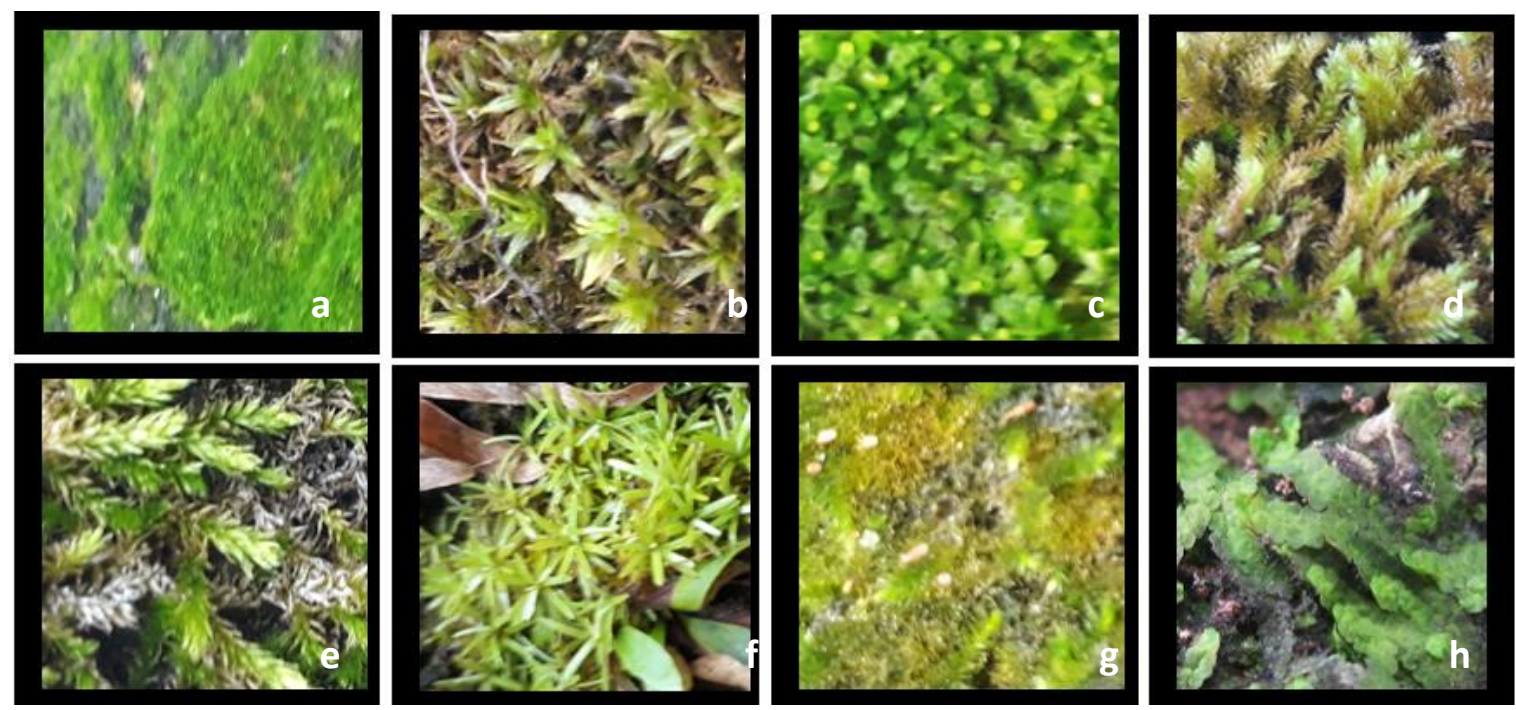

Gambar 1. Karakteristik morfologi flora epifit golongan lumut a. Daun merayap rapat (Arthrocormus schimperi), b. Daun tegak mengembang (Bryum coronatum), c. Daun tegak rapat (Calymperes pallidum,) d dan e. Daun tersusun spiral memanjang (d. Leucrobryum glaucum e. Leucobryum aduncum), f. Daun tegak, rapat mengembang (Syrhopodon prolifer), g. Daun merayap (Thuidium sp.), h. Daun merayap menyerupai thalus ( Pallavicinia sp.)

Famili Bryaceae mempunyai rhizoid berwana coklat, batang tegak dengan panjang batang bervariasi dari sekitar $2 \mathrm{~cm}$ sampai $20 \mathrm{~cm}$ pada Rosulabryum subtomentosum, dan mempunyai daun tersusun spiral dengan warna yang bervariasi seperti putih, hijau keperakan, hijau, hijau kemerahan, coklat merah dan ungu (Spence 2014).

Anggota famili Calymperaceae, mempunyai struktur daun yang terkonsentrasi pada bagian basal seperti dijumpai pada genera yang ditemukan pada penelitian ini yaitu Arthrocormus, Calymperes dan Syrrhopodon. 


\section{Kunci identfikasi lumut epifit}

1a. Lumut berdaun ................................................................... 2

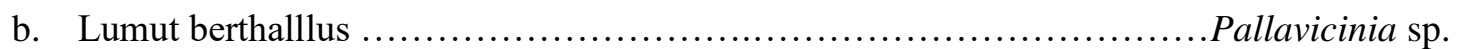

2a. Pertumbuhan merayap atau agak tegak, batang sedang, hijau........................ 3

b. Pertumbuhan merimbun, batang tebal, coklat gelap. Callicostella papillata var. prabaktiana

3a. Pertumbuhan tegak (acrocarpus), percabangan pinate ................................ 4

b. Pertumbuhan merayap , percabangan bi atau tripinate ....................... Thuidium $\mathrm{sp}$.

4a. Warna daun hijau pucat keputihan ............................................ 5

b. Warna daun hijau atau hijau kekuningan ...................................... 7

5a. Batang sekitar $15 \mathrm{~mm}$ atau lebih, daun hijau keputihan terutama bagian ujung ......... 6

b. Batang sekitar10 - $12 \mathrm{~mm}$, daun hijau pucat ............................ Leucrobryum glaucum

6a. Pertumbuhan sering tersebar, daun bagian ujung putih kehijauan......Leucobryum aduncum

b. Pertumbuhan mengelompok, daun ujung hijau sedikit putih......... Leucobryum candidum

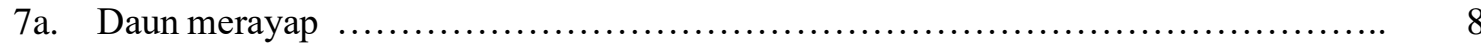

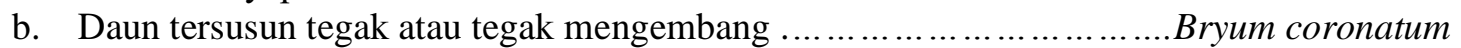

8a. Tepi daun jelas............................................................ 9

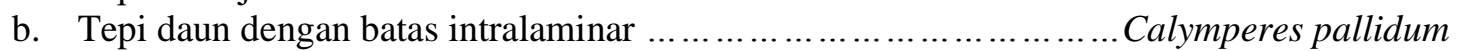

9a. Daun hijau hijau kekuningan dengan bercak merah jambu .......................... $\quad 10$

b. Daun hijau tanpa bercak ............................................. Arthrocormus schimperi

10a. Basal helai daun melebar, sekitar 6-8 mm, ujung daun melekuk .................. 11

b. Basal helai daun lurus, sekitar $4 \mathrm{~mm}$, ujung daun runcing........ Syrrhopodon aristifolius

11a. Tepi helai anak daun bagian atas bergerigi .................... Syrrhopodon albo-vaginatus

b. Tepi helai anak daun bagian atas rata ................................... Syrhopodon prolifer

Jenis jenis paku epifit

Sebanyak 21 paku epifit ditemukan pada kajian ini, dan tergolong dalam 7 famili yang tergolong dalam 2 ordo yaitu Glechneiales, Famili Glecheniaceae (1 jenis) serta ordo Polypodiales dengan 6 famili yaitu Apleniaceae (3 jenis), Blecnaceae (1 jenis), Davalliaceae (3 jenis), Nephrolepidaceae (1 jenis), Polypodiaceae (10 jenis) dan Pteridaceae (4 jenis). Jumlah jenis paku epifit tertinggi dari famili Polypodiaceae hal ini sesuai dengan kajian Sofiyanti (2013), Zhang et al. (2013a) dan Sofiyanti et al. 2017a. Gambar 2 menunjukan contoh karakteristik jenis paku epifit yang ditemukan. Glechneniaceae merupakan satu satunya famili dari ordo Glecheniales yang ditemukan pada penelitian ini. Famili Glecheniaceae mempunyai karakteristik habitus yang membentuk semak rimbun, rhizome menjalar panjang dengan pinna mempunyai percabangan pseudodikotom dengan pertumbuhan tunas di antara cabang tersebut (Perrie \& Brownsey 2015). Sedangkan sori berbentuk orbikular $1-3$ baris (Jin et al. 2013).

Pada ordo Polypodiales ditemukan 6 famili yang mempunyai karakteristik sebagai berikut :

- Aspleniaceae : rhizome biasanya pendek menjalar atau agak tegak. Pinna mengelompok atau agak jarang (Kramer \& Ronald 1990), sori berbentuk garis dan terletak di kanan kiri tulang daun atau anak daun (Lin \& Viane 2013).

- Blechnaceae: rhizome tegak atau menjalar, merupakan paku monomorfik atau dimorfik (De Gasper et al. 2016), daun muda

- kemerahan dengan sori yang melekat pada sepanjang kanan kiri tulang daun (Wang et al. 2013).

- Davalliaceae: pada umumnya epifit dengan rhizome bersisik, menjalar. Daun tersebar, tunggal atau majemuk ganda dengan bentuk lamina triangular dan sori berada pada lekukan pinula (Xing et al. 2013).

- Neprolepidaceae: berdaun majemuk bentuk lanset dan diselubungi rambut 
terutama saat muda, sori berbentuk ginjal dnegan indusium sejati (Xing et al. 2013).

- Polypodiaceae: pada umumnya epifit, rhizom menjalar dengan daun dimorfik (Zhang et al. 2013b), tebal atau kaku.
- Pteridaceae: umumnya terestrial dan monomorfik, daun tunggal atau majemuk (kaku, meneyerupai kertas atau herbaceous) (Zhang et al. 2013a), sori yang beragam dari bentuk dan posisinya.
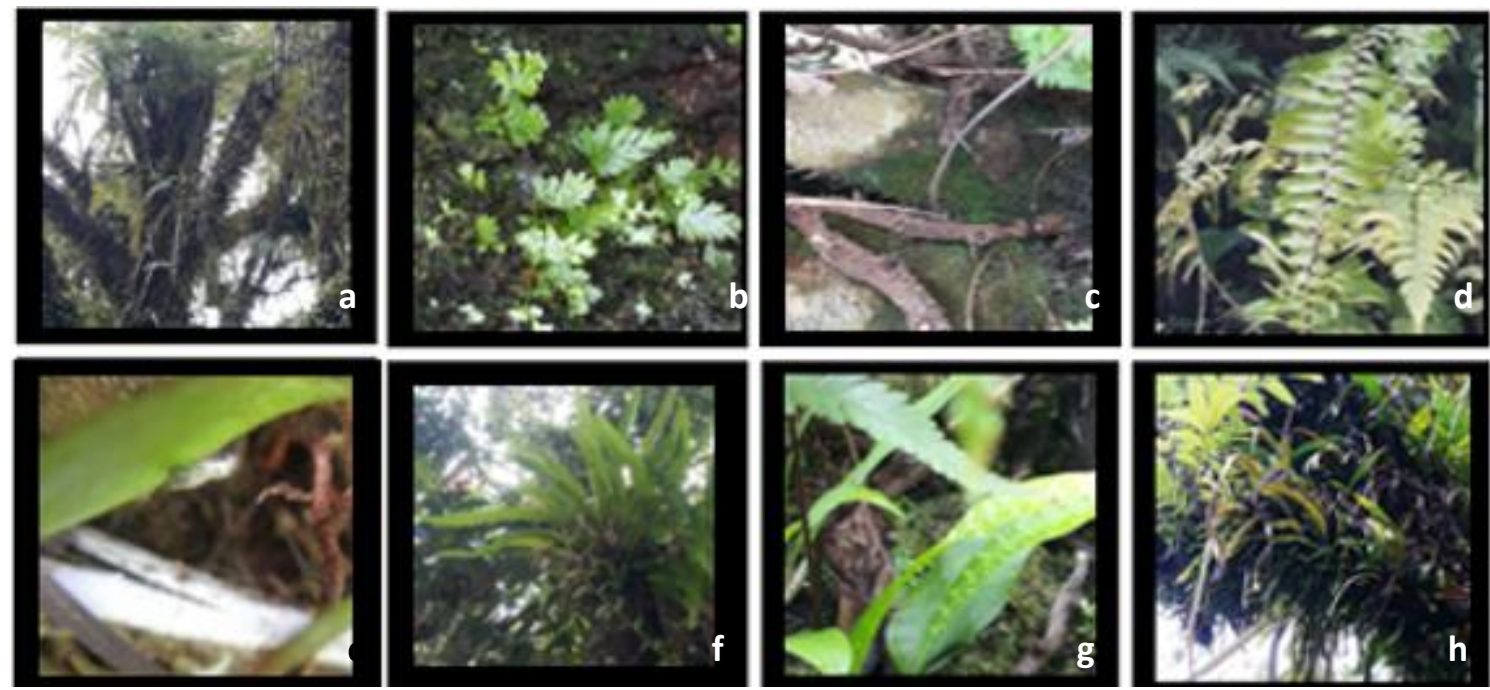

Gambar 2. Contoh karakteristik paku epifit pada Hutan Kota Pekanbaru. a. habitus herba paku epifit pada inangnya, b. Daun majemuk ganda pada Davallia denticulata, $c$. Rhizom merayap bersisik (Davallia sp.,) d. Daun majemuk (Nephrolepis hirsutula), d. Daun tunggal berdaging (Pyrrosia lanceolata), e. Daun yang tersusun roset (Microsorum punctatum), f. Daun lerlekuk (Pymatosorus scolopendria) g. Daun dimorfik (Pyrrosia longifolia

\section{Kunci identifikasi paku epifit}

1a. Batang tidak bercabang atau bercabang tidak beraturan .............................. 2

b. Batang bercabang dikotom .................................... Dicranopteris linearis

2a. Sori tersebar di permukaan bawah daun, ujung anak daun atau tepi daun ............... 3

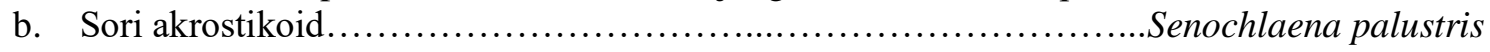

3a. Sori berada di lekukan anak daun ............................................. 4

b. Sori berada di permukaan bawah anak daun atau sepanjang tepi daun ..................... 6

4a. Rhizom coklat tua atau coklat kekuningan...................................... 5

b. Rhizom hitam ............................................................

5a. Rhizom coklat tua, daun steril sekitar 40 x $20 \mathrm{~cm} \ldots \ldots \ldots \ldots \ldots \ldots \ldots \ldots$. Davallia $\mathrm{sp} 2$.

b. Rhizom coklat kenunginan, daun steril bias mencapai $70 \times 45 \mathrm{~cm}$...... Davallia denticulata

6a. Daun muda hijau ............................................................... 7

b. Daun muda hijau kemerahan ................................................. 19

7a. Daun muda berambut coklat, tidak menghasilkan umbi ............................... 8

b. Daun muda berambut putih, tebal, berumbi ......................... Neprolepis hirsutula

8a. Daun tersusun roset .......................................................... 11

b. Daun tersebar sepanjang rhizom ........................................... 14

9a. Sori berbentuk garis di sepanjang kanan kiri tulang daun atau anak daun ............... 12

b. Sori berbentuk bulat, keci tersebar di bawah permukaan daun....................... 13

10a. Daun lanset, tengah melebar, hijau tua, sekitar $250 \mathrm{~m}$ x $30 \mathrm{~cm}$.............Asplenium nidus

b. Daun memanjang, hijau terang, sekitar $200 \times 17.5 \mathrm{~cm}$.................Asplenium serratum

11a. Daun monomorrfik.......................................................... 14 
b. Daun dimorfik ....

12a. Daun lanset, ujung meruncing.... Microsorium pustulatum

b. Daun memanjang, ujung berlobus dan melebar Microsorum puctatum

13a. Daun tidak mempunyai polimorphisme, rhizome coklat 16

b. Daun mempunyai polimorfisme, rhizome kehijauan ...............Phymatosorus scolopendria

14a. Rhizom panjang dan menjalar, daun tersebar ................................... 17

b. Rhizom pendek, daun tersusun menumpuk, daun steril berada di bawah ................. 20

15a. Daun steril lancet atau garis .................................................... 18

b. Daun steril membulat atau oval ................................... Pyrrosia piloselloides

16a. Daun kaku dan tebal, hijau gelap ............................................. 19

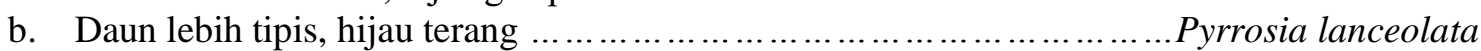

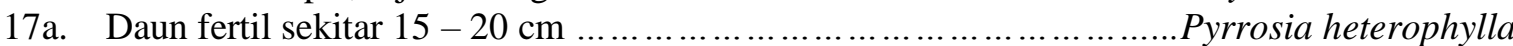

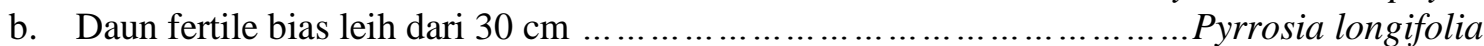

18a. Daun fertil berlekuk menyirip berlekuk, $40-50 \times 20 \times 25 \mathrm{~cm}$; daun steril lerlekuk, bentuk membulat, $25 \times 20 \mathrm{~cm}$

Drynaria sparsisora

b. Daun fertil bercabang banyak, menjuntai, bis amencapai $100 \mathrm{~cm}$; daun steril menyerupai mangkuk pada again basal, berdaging dengan bagian ujung lebih tipis, sekitar 25 x 40

Platycerium coronarium

19a. Daun hijau terang, agak tipis, tepi daun agak bergelombang ...................... 20

b. Daun hijau gelap, saat muda kemerahan, tebal, tepi daun rata...................... 21

20a. Daun berukuran mencapai $50 \times 2 \mathrm{~cm}$, tepi agak bergelombang .........Vittaria scolopendrina

b. Daun berukuran $40 \times 0.8 \mathrm{~cm}$ tepi rata Vittaria graminifolia

21a. Daun linear, berukuran hampir sama dari basal sampai ke ujung daun ... Vittaria ensiformis

b. Daun lanset, bagian tengah agak lebar Vittaria lanceolata

Jenis tumbuhan berbiji epifit

Pada kajian ini hanya ditemukan 2 jenis tumbuhan berbiji yang epifit di lokasi kajian, yaitu anggrek Acriopsis liliifolia (Gambar 3a) dan Dendrobium crumenatum
(Gambar 3b) dari famili Orchidaceae. Keberadaan kedua jenis ini juga telah dilaporkan oleh Sofiyanti (2014) yang merupakan anggrek epifit pada pohon rambutan.
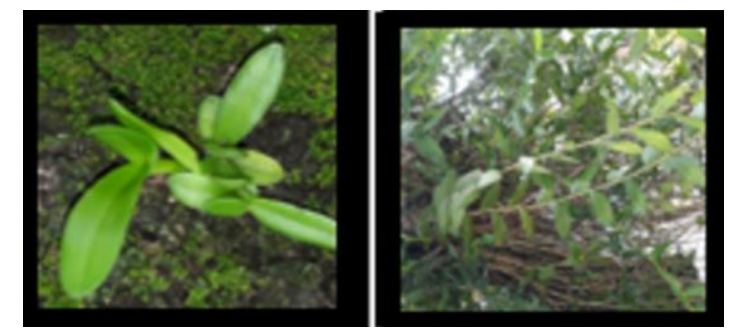

Gambar 3. Tumbuhan berbiji yang epifit. a. Acriopsis liliifolia, b. Dendrobium crumenatum

\section{Kunci identifikasi tumbuhan berbiji epifit}

1a. Daun tunggal, permukaan pseudobulb beralur kasar, daun memanjang, sekitar $20 \times 2.5 \mathrm{~cm}$ atau lebih, karangan sekitar $2-30 \mathrm{~cm}$; petal 5 $\mathrm{mm}$ warna putih kekuningan, tidak beraroma ........... Acriopsis liliifolia b. Daun majemuk, permukaan pseudobulb agak halus, daun agak oval, sekitar $40-60 \mathrm{~cm}$, karangan bunga sekitar $80 \mathrm{~cm}$ atau lebih; petal sekitar $4 \mathrm{~cm}$ putih, beraroma harum..........Dendrobium crumenatu 


\section{Analisis kekerabatan flora epifit}

Karakterisasi morfologi telah dilakukan pada setiap jenis flora epifit yang ditemukan. Hasil karakterisasi dilanjutkan dengan pembuatan skor karakter dan dianalisis menggunakan NTsyst untuk membuat pohon kekerabatan (dendrogram). Gambar 4 menunjukan dendrogram hasil pengelompokan. Kooefisisen similaritas yang diperoleh berkisar antara $0.40-0.96$. Dendrogam hasil pengelompokan menunjukan 2 kelompok (I dan II) yang semua anggotanya mengelompok pada koefisien similaritas 0.10 . karakter yang membedakan kedua kelompok adalah ada tidaknya thalus, spora, berkas pengangkut, dan ada tidaknya bunga, buah dan biji

Kelompok I merupakan kelompok tumbuhan berspora, yang mengelompok pada koefisien similaritas 0.42 . Kelompok ini terdiri dari golongan lumut (sub kelompok IA) dan paku (sub kelompok IB). Kedua subkelompok ini menyatu karena mempunyai kesamaan karakter yaitu menghasilkan spora, mempunyai pergantian fase gametofit dan sporofit serta belum mempunyai kormus. Sub kelompok IA terdiri dari semua jenis lumut dan mengelompok pada koefisien similaritas 0.42 . Tumbuhan lumut tidak mempunyai berkas pengangkut dan generasi yang dominan adalah generasi gametofit, karena gametodit mempunyai siklus hidup yang lebih lama dan mendukung sporofit (Sofiyanti et al. 2017a). Pada sub kelompok ini, jenis lumut Pallavicinia sp. (Divisi Marchantiophyta) memisah dari jenis lumut lainnya yang tergolong Divisi Bryophyta.

Pada anggota Marchantiophyta, masih mempunyai tubuh yang berthalus, merayap dengan bagian ventral ditumbuhi rhizoid dan bagian dorsal mendukung arkegonia dan antheridia. Sedangkan Divisi Bryophyta merupakan lumut daun yang tumbuh tegak dan pada umumnya sudah mempunyai daun yang jelas. Anggota Bryophyta mengelompok pada koefisien similartas 0.92 yang menunjukan hubungan kekerabatan yang dekat karena persamaan karakter yang tinggi. Sedangkan pada sub kelompok IB terdiri dari semua jenis golongan paku, mempunyai persamaan karakter yaitu sudah mempunyai berkas pengangkut sederhana (Sofiyanti et al. 2015, 2017)

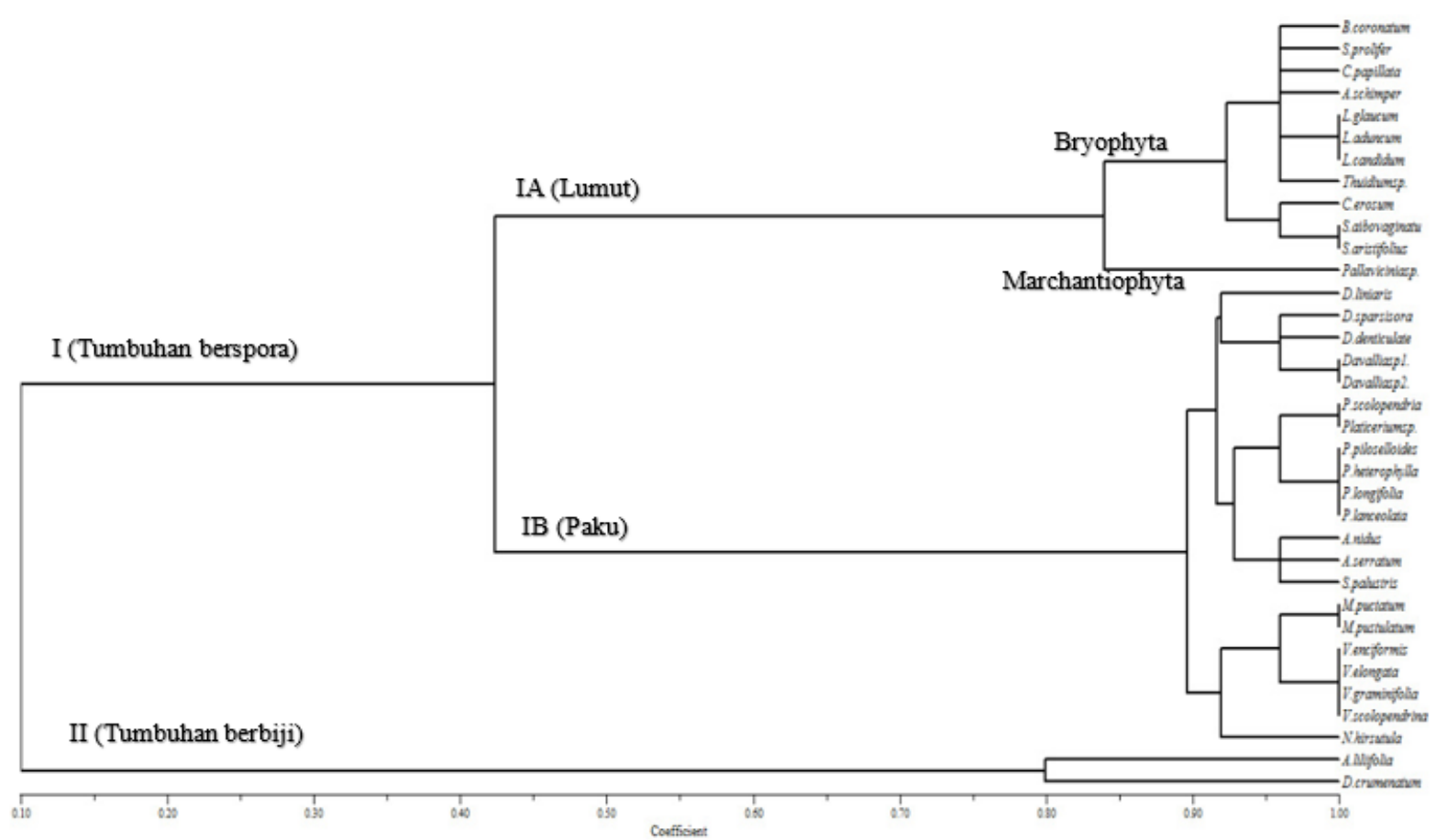

Gambar 4. Dendrogram hasil pengelompokan jenis-jenis flora epifit di Hutan Kota Pekanbaru, Ria 
Pada umumnya berkas pengangkut yang ditemukan pada tumbuhan paku adalah protostele. Tipe ini menunjukan bahwa xylem berada di tengah dan dikelilingi oleh floem tanpa adanya empulur. Karakter lain yang dimiliki tumbuhan paku adalah generasi yang dominan merupakan generasi sporofit, yang mempunayi siklus hidup panjang dan menghasilkan spora saat dewasa. Sedangkan gametofit pada tumbuhan paku berumur pendek dan jarang dijumpai.

Pada dendrogram, Kelompok II hanya terdiri dari 2 jenis tumbuhan berbiji (Spermatophyta) yang mengelompok pada kooefisien similaritas 0.80 . kedua jenis tersebut adalah Acriopsis liliifolia dan Dendrobium crumenatum. Acriopsis liliifolia mempunyai buna majemuk dengan diameter bunga tunggal sekitar $5 \mathrm{~mm}$, dan pada bagian labelum bereawna kuning dan tepal berwarna putih. Sedangkan Dendrobium crumenatum mempunyai karaangan bunga lebih panjang, bias mencapai $50 \mathrm{~cm}$ atau lebih dengan bunga putih (Sofiyanti 2014).

\section{Kesimpulan}

Pada kajian ini ditemukan 35 jenis flora epifit di Hutan Kota Pekanbaru yang terdiri dari tumbuhan lumut (12 jenis), tumbuhan paku (21 jenis) dan tumbuhan berbiji (2 jenis).

\section{Daftar Pustaka}

Crandall-Stotler BJ \& SE. BartholomewBegan. 2018. Morphology of Mosses (Phylum Bryophyta). (Diakses : 10 November 2018. Http://Flora.Huh.Harvard.Edu/Flora data/001/Webfiles/Fna27/Fna27Chapter1.Pdf.

De Gasper A, V Dittrich, AR Smith \& S. Alexandre. 2016. A classification for Blechnaceae (Polypodiales: Polypodiopsida): New genera, resurrected names, and combinations. Phytotaxa. 275. 191227. 10.11646/phytotaxa.275.3.1.
Gupta, VN. and AK Asthana. 2016. Present Status Of Family Dicranaceae (Bryophyta) In Pachmarhi Wildlife Sanctuary, Central India Reesa Taiwania 61(3): 253-259 Doi: 10.6165/Tai.2016.61.253 253

Hassel, K., H. Zechmeister and T Prest $\varnothing$. 2014. Mosses (Bryophyta) And Liverworts (Marchantiophyta) Of The Zackenberg Valley, Northeast Greenland. Lindbergia 37: 66-84, 2014

Ireland RJ. 2007. Dicranaceae Schimper . Flora Of North America 27: 358 372.

Jin, X.F., B.Y. Ding \& K. Iwatsuki. 2013. Gleicheniaceae. Pp. $110-115$ in Z. Y. Wu, P. H. Raven \& D. Y. Hong, eds., Flora of China, Vol. 2-3 (Pteridophytes). Beijing: Science Press; St. Louis: Missouri Botanical Garden Press.

Klazenga,N. 2012. Australian Mosses Online. 33. Dicranaceae.

http://www.anbg.gov.au/abrs/Mosse s_online/Dicranaceae.pdf (2012)

Kramer, K. and R. Viane 1990. Aspleniaceae. 52-57. (In $\mathrm{The}$ Families and Genera Of Vascular Plants. Edited By K. Kubitzki Vol. I: Pteridophytes. Springer-Verlag. Berlin Heidelberg. 10.1007/9783-662-02604-5_14.

Lavate R., Patil S, Dongare M, Sathe S \& Magdum S. 2018. Pallavicinia lyellii (Hook.) Gray, (Pallaviciniaceae): an addition to the hepatic flora of Maharashtra, India. Plant Science Toda 2(4): $192-196$.

Lin, Y.X. \& R. Viane. 2013. Aspleniaceae. Pp. 267-316 in Z. Y. Wu, P. H. Raven \& D. Y. Hong, eds., Flora of China, Vol. 2-3 (Pteridophytes). Beijing: Science Press; St. Louis: Missouri Botanical Garden Press.

Perrie R. and P.J. Brownsey. 2015. Flora of New Zealand [electronic resource] : ferns and lycophytes. Fascicle 12, Gleicheniaceae / L.R. Lincoln, N.Z. : Manaaki Whenua Press. 
Piggott, A.G. 1998. Fern of Malaysia in Color. Tropical Press Sdn.Bhd., Malaysia.

Silva AG. and PB Schwartsburd. 2016. Ferns of Viçosa, Minas Gerais State, Brazil: Polypodiaceae (Polypodiales, Filicopsida, Tracheophyta). Hoehnea 44(2): 251-268. http://dx.doi.org/10.1590/22368906-95/2016

Soares AER and Câmara PEAS. 2015. A new species of Thuidium (Thuidiaceae) from Brazil, and a key to the Brazilian. The Bryologist 118(2), pp. 178-183

Sofiyanti, N. 2013. The diversity of epiphytic fern on the oil palm tree (Elaeis guineensis Jacq.) in Pekanbaru, Riau. Jurnal Biologi Jurusan Biologi FMIPA Udayana,XVII (2)

Sofiyanti N. 2014. Perbandingan morfologi dua jenis anggrek epifit pada pohon rambutan (Nephelium lappaceum): Acripsis liliifolia dan Dendrobium crumenatum ,Jurnal. Biologi Lingkungan Al Kauniyah 7(1):

Sofiyanti N, D. Iriani, A.A. Roza. 2015a. Morfologi tumbuhan Paku di Taman Hutan Raya Sultan Syarif Hasyim, Riau. Unri Press, Pekanbaru.

Sofiyanti N, Iriani D, Fitmawati, Roza AA. 2015b. Stenochlaena riauensis (Blechnaceae), A new fern species from Riau, Indonesia. Bangladesh Journal of Plant Taxonomy 22(2): 137-14.

DOI http://dx.doi.org/10.3329/bjpt.v22i2. 26075.

Sofiyanti N, Iriani D, Fitmawati, and Marpaung, A.A. 2017a. A Note on the Fern (Pteridophyte) Diversity from Riau. Applied Science and Technology 1(1): 478 - 481.

Sofiyanti, N., Fitmawati, FS. Fastanti 2017b. Tumbuhan Lumut Bryobiotina di Provinsi Riau. UNRI Press.
Wang, F.G., F.W. Xing, S.Y. Dong \& M. Kato. 2013. Blechnaceae. Pp. 411417 in Z. Y. Wu, P. H. Raven \& D. Y. Hong, eds., Flora of China 2-3 (Pteridophytes). Beijing: Science Press; St. Louis: Missouri Botanical Garden Press.

Xing, F.W., F.G. Wang \& H.P. Nooteboom. 2013. Davalliaceae. Pp. 749-757 in Z. Y. Wu, P. H. Raven \& D. Y. Hong, eds., Flora of China 2-3 (Pteridophytes). Beijing: Science Press; St. Louis: Missouri Botanical Garden Press.

Xing, F.W., F.G. Wang \& P.H. Hovenkamp. 2013. Nephrolepidaceae. Pp. 727729 in Z. Y. Wu, P. H. Raven \& D. Y. Hong, eds., Flora of China 2-3 (Pteridophytes). Beijing: Science Press; St. Louis: Missouri Botanical Garden Press

Zhang, G.M., W.B. Liao, M.Y. Ding, Y.X. Lin, Z.H. Wu, X.C. Zhang, S.Y. Dong, J. Prado, M.G. Gilbert, G. Yatskievych, T.A. Ranker, E.A. Hooper, E.R. Alverson, J.S. Metzgar, A.M. Funston, S. Masuyama \& M. Kato. 2013a. Pteridaceae. Pp. 169-256 in Z. Y. $\mathrm{Wu}, \mathrm{P}$. H. Raven \& D. Y. Hong, eds., Flora of China 2-3 (Pteridophytes). Beijing: Science Press; St. Louis: Missouri Botanical Garden Press.

Zhang, X.C., S.G. Lu, Y.X. Lin, X.P. Qi, S. Moore, F.W. Xing, F.G. Wang, P.H. Hovenkamp, M.G. Gilbert, H.P. Nooteboom, B.S. Parris, C. Haufler, M. Kato \& A.R. Smith. 2013b. Polypodiaceae. Pp. 758-850 in Z. Y. Wu, P. H. Raven \& D. Y. Hong, eds., Flora of China 2-3 (Pteridophytes). Beijing: Science Press; St. Louis: Missouri Botanical Garden Press. 